University of Nebraska - Lincoln

DigitalCommons@University of Nebraska - Lincoln

To Improve the Academy

Professional and Organizational Development Network in Higher Education

1994

Section IV: Classroom Practices for Teaching Improvement

Follow this and additional works at: https://digitalcommons.unl.edu/podimproveacad

Part of the Higher Education Administration Commons

"Section IV: Classroom Practices for Teaching Improvement" (1994). To Improve the Academy. 323. https://digitalcommons.unl.edu/podimproveacad/323

This Article is brought to you for free and open access by the Professional and Organizational Development Network in Higher Education at DigitalCommons@University of Nebraska - Lincoln. It has been accepted for inclusion in To Improve the Academy by an authorized administrator of DigitalCommons@University of Nebraska - Lincoln. 


\section{Section IV}

\section{Classroom Practices for Teaching Improvement}

Actively engaging students in the learning process and providing them with opportunities to work cooperatively improve student learning. Cottel and Millis describe "Complex Cooperative Learning Structures for College and University Courses" and provide suggestions for instructional developers who may wish to introduce cooperative learning to their faculty. In "Conducting the Cooperative Case," Millis combines case study methodology with cooperative learning techniques and shows how the technique can be used with both faculty and students.

In "The Value of Classroom Humor" Nichols, Amick, and Healy argue that humor, properly used, can enhance student learning. They present a workshop and materials that can be used with faculty to introduce appropriate humor into the classroom. 